Review of Arts and Humanities

June 2015, Vol. 4, No. 1, pp. 80-90

ISSN: 2334-2927 (Print), 2334-2935 (O nline)

Copyright (c) The Author(s). All Rights Reserved.

Published by American Research Institute for Policy D evelopment

D O I: $10.15640 /$ rah.v4n1a10

URL: http:/ / dx.doi.org/ 10.15640/ rah.v4n1a10

\title{
Video Art by Mexican Women Artists in the 21st Century. Context and Dissemination
}

\author{
Xesqui Castañer López ${ }^{1}$
}

\begin{abstract}
The new art history arises, from an interdisciplinary view, theoretical and practical embodiment issues related with contemporary art and its inclusion and development in university world. At the same time, gender studies have been incorporated into the development of postgraduate curriculum, placing value on the art work of women, continuing the contestation to the canon already started in the twentieth century. These gender discourses have assumed new technologies as the most versatile media format with unlimited field for image dissemination. Consequently, in the context of globalization, the intangible and digital formats have become priority means when developing feminist and post-feminist theories in the arts. The choice of the audiovisual media is due to the fact that, from the beginning, they seem to be critical tools where space and time converge. In a globalized world, the feminist study of image is very important in a society where the media are the most powerful tool to control social imaginary, and it is in this speech where new technologies, particularly video, are established as the best means for creating female images.
\end{abstract}

Keywords: technology, genre, visual culture, history of art, contemporary, feminism

\subsection{Introduction}

The historiographic discourse exists, but it is very fragmented (Sedeño, 2006). Sarah Minter (2008), the video producer, Erandy Vergara, the curator, and Fernando Llanos (2004) recently conducted a project called Salta pa'tras, which sought to bring together the fragmented history of video in Mexico (Baigorri, 2008). At the 2002 Vidarte Festival, Sarah Minter herself spoke of the lack of history and reflection about Mexican video productions, both in the national and international context (Minter, 2008). And that is the context in which we will consider the output of women in this medium (Debroise, 2006). The video as a new artistic tool has been consolidated as an image constructor for Mexican women artists, which as, Márgara Millán (1996) points out, is a flexible and truly appropriate technology for the introspection of women's creative work (Renaud, 1990). The history of the feminist video dates back to the 1960s, in the framework of the debates and strategies, and of the political and social militancy of that time (Elkins, 2003). Cynthia Pech (2006) has reflected on the contribution of post-structuralist feminist theory to the debate to recover the female experience as a political place (Pech, 2009). There are currently many women video producers in Mexico, who are committed to the creative process from different positions (Ranucci, 1998). Y et they do not all do so from a feminist perspective. However, the video is a highly ideal medium for feminist practice, taken as a set of critical and reflective discourses on the condition of real women. The woman who self-represents based on intimate introspective offerings to depict her closest reality. The video is thus understood as space, place, time and text where women dare to reveal themselves and be seen. This medium serves as a political expression to visualise the invisible (G arcía, et al., 2006).Pola Weiss (1947-1990) pioneered early video art in Mexico.

${ }^{1} \mathrm{PhD}$ in History of Art from the Universidad del País Vasco / EHU and Senior Lecturer in History of Art (Universitat de València-Estudi General) Department of History of Art. Director of the Master's Programme "History of Art and Visual Culture". Phone: +34649839162, Email: xesqui.castaner@uv.es 
This dancer, teacher and researcher showed her video Flor Cósmica at the Carrillo Gil Museum in the 1960s, in a completely isolated context. Her most important contribution lay in the creation of images using the body, and the mixture of documentary-chronicle and fiction to be found there. She used the camera as a means to digress into own worlds. In her creations, she self-depicts, using the shadows of her silhouette and the different elements of her body that make it up (Hernández Miranda, 2006). With more than thirty exhibitions to her name not only in Mexico, but also at well-known institutions, such as George Pompidou or the Venice Biennale, she is one of the most important references of electronic images as a means for electro-sensorial and even multi-media, alternative, expressive, conceptual and plastic experimentation. In her videos, dance is combined with the video, this with performance, and both with psychoanalysis. Her most outstanding works include: Mi Corazón (1986) (Figure 1.1), Exoego Danzarima Venusina, Las tasas deinteés (1 (Fi983), La pueta decistal, Vidanza espacial yVidecrigen (Zúñiga, 2004). Memory, sets of colour, change of perspective and sound repetitions are all aspects in her work, even though there is certain feminist attitude, that is both fun and, of course, social. Pola Weiss committed suicide in 1990 in front of a video camera (García et al., 2006).

Figure 1.1: Pola Weiss, Mi co-ra-zon, 1986 @artist

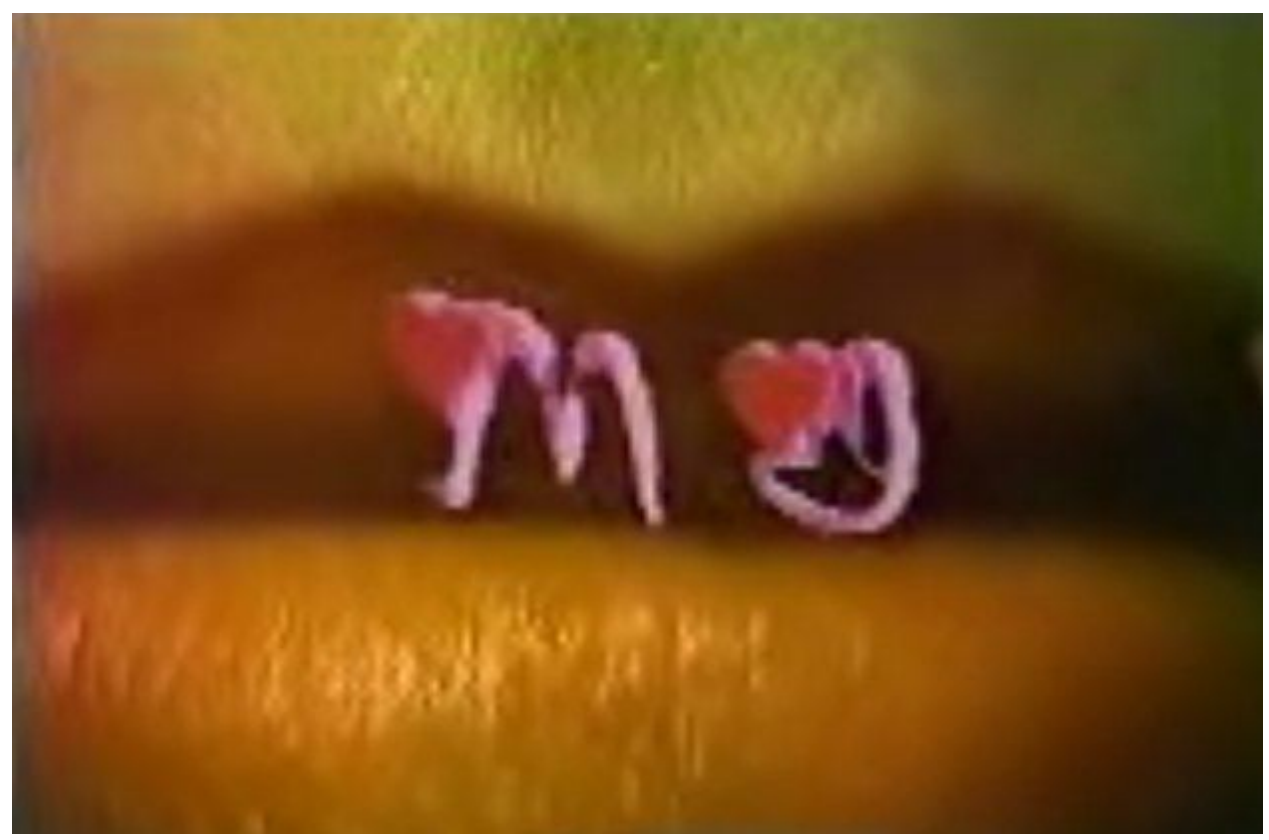

\subsection{Videoartist women 1980s}

In the 1980s, more importance was given to the social contents and the first broadcast events were produced. Based on the earthquakes in Mexico City in 1985, an individual and collective videos in groups were developed and which began to make their mark as small independent companies. In 1986, the first Videofilme Fair was organised by Rafael Corkidhi. It was the forerunner of the Biennales and was likewise an opportunity for independent producers to exchange ideas. From that time onwards, video filmmakers worked on projects and pushed the boundaries of the medium, by laying the foundations to diversify into genres and hybrids. There is a worldwide interest in social themes. When the medium is disencumbered of formal issues and confronted with television, contents are triggered that point towards the surrounding reality (González \& Lerner, 1998). The video is undoubtedly the medium that provides an ideal way to explore the female body and continue to experiment in the way that had previously occured in literature. According to Ana Sedeño: (... ) This re-assessment also took place in the development of Mexican videography, and even more so, if you take into account that identity comes from the other concept at play. The country and the wealth of its ethnos and identities emerge from the other concept at play. The country and the wealth of its ethnos and identities, along with the female gender as a means of being in the world have led to enriching videographic works, at a time where hybridisation is one of the most powerful cultural drivers (... ) (Sedeño, 2006). 
Artists such as Sarah Minter, Pilar Rodríguez, Julia Barco, Mari Carmen de Lara, Susana Quiroz or Inés Morales, are on this list, even though the practical and theoretical contributions do not have the same importance (Mariategui \& Villacorta, 2005). The work of Sarah Minter (1953) has developed between theory and practice, and her contributions along with her former partner, Gregorio Rocha, were very interesting. The docu-fiction works in conjunction with strips of zones on the fringe of the great metropolis, are a characteristic mark of videos such as Nadie sinocente(1987) (Figure 2.1) or Alma punk (1992) (Minter, 1991-92). The latter tells the history of a disillusioned female punk living on the edge of society and who climbs over the frontier fence in Tijuana to escape to the United States. In the sphere of video-installation, she also experimented with results that have influenced a whole generation of Mexican video filmmakers. In the field of video installation, her main contribution has been to break with the museum-graphic custom of showing everything on a single screen with different simultaneous windows, which limits and slightly messes up the existence of each work and its connection with the other contents. This is put into practice in her video installation, Intervalos (2005), where she prepares 16 video-sequences that function, however, independently. Autonomous narrative units that seek to generate a personalised reading of everything, by means of the journey of the viewer. This gamble is interesting for the spatial reading approach that links the mono-channel units. The videos shown on the monitors are Hikun, where the authoress travels in the dessert along with her partner, Automerato 1 and the romantic Thefirst bath (2006), shown individually in 2007 at the Mexican Video Art Marathon and the Barcelona Festival Loop, in that same year (Minter, 2008).

Figure 2.1: Sarah Minter, Nadie es Inocente, 1987 Cartista

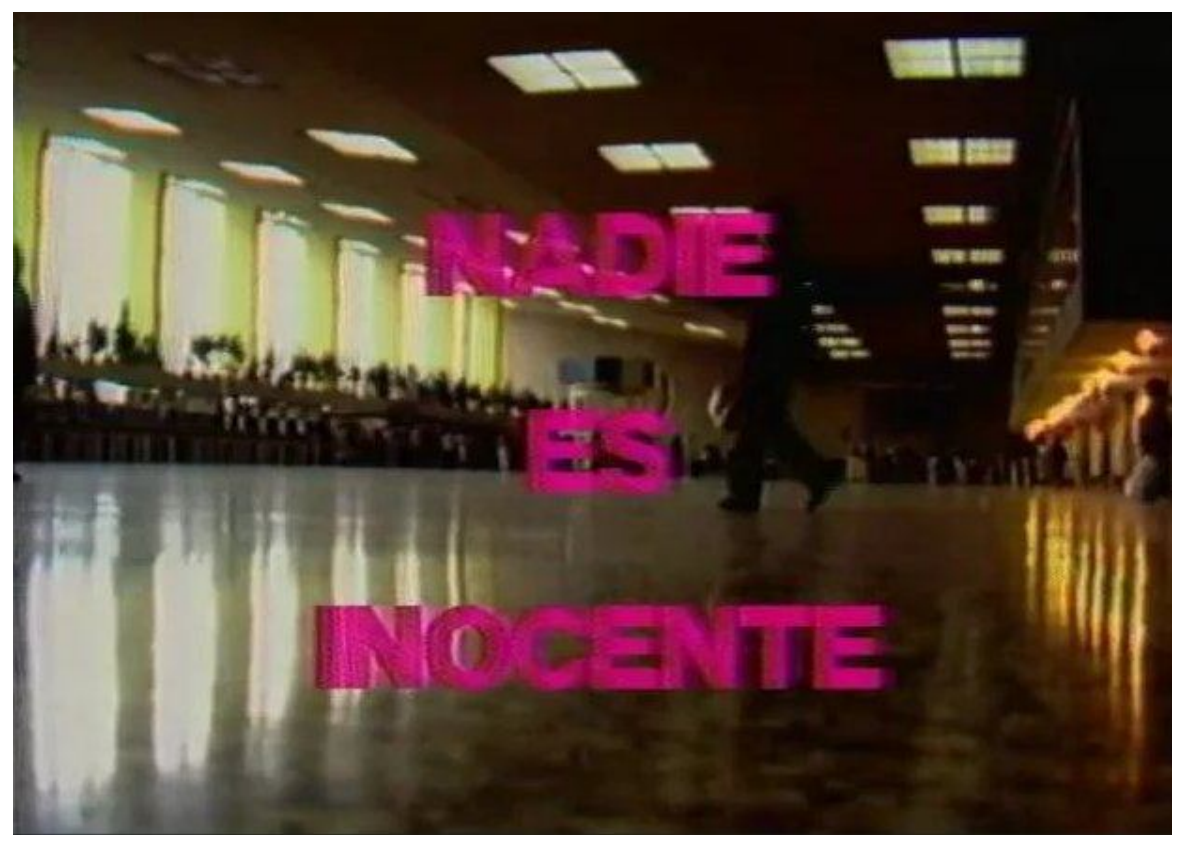

In the public sphere, she, along with other individuals, have generated broadcasting projects such as "La sala del deseo" at the Centro de la Imagen. At the start of the 1990s, she organised the country's first video workshops at the Casa del Lago, and at the end of that same decade, she set up, at the "La Esmeralda" school at the Centro Nacional de las Artes (Mexican National Arts Centre), the video workshop where many artists trained who currently are working with this format. A part from continuing to develop project, she is currently part of a research network to reconstruct the history of Mexican video art (Malvido Ariaga, 1999). Her work has been exhibited inside and outside Mexico. Her work has won prizes at the La Habana International Film Festival and at the Mexican Film Festival. Apart from producing her own works, she has taught at the Universidad Iberoamericana and at the Centro Nacional de las Artes (CENART) in Mexico D.F.. She has been awarded Rockefeller Foundation, MacArthur and FONCA scholarships. In 2003, she spent time in Berlin and in 2006, in Cristiania, The Free Town (D enmark) to work on the Multivese project about utopian communities around the world (Debroise \& Medina, 2006). Video-art, specifically featuring the indigenous and gender, contains radical reading and writing projects. Multi-ethnic, multi-directional, interdisciplinary and non-linear writing is typical. 
According to Araceli Zúñiga: (... ) indigenous video filmmakers from urban and rural communities in Mexico have combined points of view in their audiovisual productions that reflect the wealth and diversity of the indigenous population (... ), with one of the most recognisable feature of the indigenous video in Mexico being the role that the community plays in the process, by either impacting directly or from the imagination of the authors (...) (Zúniga, 2009). Julia Barco (1953) works between Mexico D.F., Oxaca City and Colombia. She studied Communication Science at the University of Comell and a Master's in Visual Studies at MIT (Massachusetts Institute of Technology), both in the USA. Her main technical contribution has been based on the fragments which create an internal barrage to change the appreciation of the viewer. During the 1980s, she moved to Mexico to work on her thesis on the Isthmus. The contact with the Mexican culture, the indigenous cultures and communities opened up her eyes and mind. In Mexico City, she discovered the NGO s linked to feminism, to woman's rights and working to fight domestic abuse. She produced social and educational videos on these themes. Yet she did not begin to experiment until she started to work with a good quality but small camera, which she used to take shots that she later edited on her computer. A dozen works make up the main filmography of Julia Barco: Slowfood, maíz nuestro decada dia, where an indigenous woman makes the perfect dough for the perfect tortilla. Wdcometo TheShinkansen, the name of the fast train in Japan which is a pretext to pay homage to Japanese aesthetics in that toing and froing of technological frenzy and Zen calm. Chekpoint/ Paso, is a dual reading of the walls that used to divide Berlin and now increasingly separate the inhabitants of Mexico and the United States. Framed Cuadros, notes in the form of a diary about the persistence of vision. Latitudes is a recreation about North-South clashes. Chdasypañudos, shows eroticism and games at a traditional festivity in Juchitán, $\mathrm{O}$ axaca.

The work of Mari Carmen de Lara (1957), the filmmaker, is in the same vindictive lines using documentary videos. Spirited and focused on feminist issues, she has become the most prolific Mexican documentary makers, with more than thirty short-, medium- and feature length films to her name. Her documentaries directly question the taboos that continue to mark the social history of Mexico: the decriminalisation of abortion, the abuse of women within the family, reproductive health, AIDS, the exploitation of female workers, gender inequality. Opera Femine features fragments of her most typical and censured works, such as Noles peedimos un viajea la luna (1985) (Figure 2.1.1), a film document that covers the social and political consequences of the 1985 earthquake in Mexico, where she highlights the sweatshop conditions of female seamstresses and harshly criticises the figure of the President. The producer also accounts her social and personal concerns as a woman forged in and with the feminist thought of the 1960s, and how she has taken it on board though filmmaking and her social commitment (Noriega \& López, 1996).

Figure 2.2: Mari Carmen de Lara, No les Pedimos un viaje a la luna, 1985 Cartista

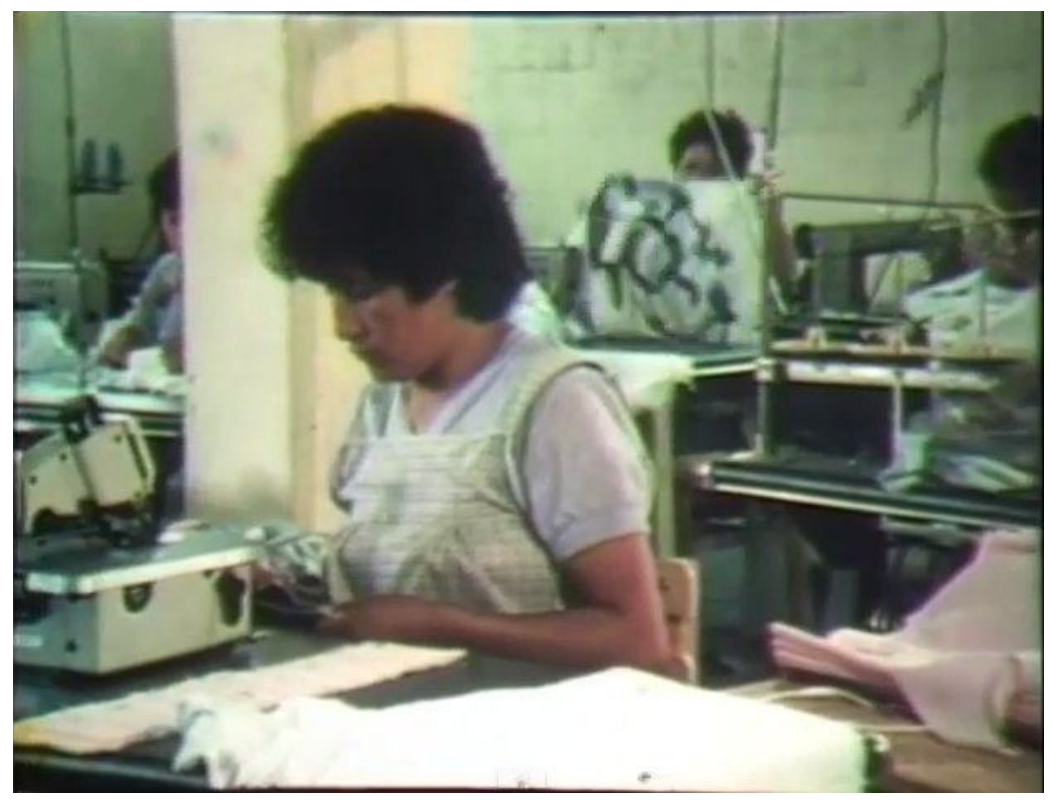




\subsection{Videoartist Women 1990s}

In the 1990s, the "Culture" institution legitimised video through events and exhibitions showcasing this medium. The First Video Biennale was held and it was subsequently followed by "Vidarte", the Electronic Arts and Video Festival. Institutions such as El FO NCA have backed video projects from 1992 to the present. The Carrillo Gil Modern Art Museum set up a specific area for video, with series of conferences, round tables and backing for videographic projects (D ebroise \& Medina, 2006). In 1996, the IV Video Biennale was held at the Centro Nacional de las Artes, with video clips, documentary, video-art, experimental and fiction genres. As the same time, US institutions, such as McArthur and the Rockefeller Foundation, extended their audiovisual scholarships to Mexican artists. Festival and forums mushroomed and enabled artists such as Ximena Cuevas to position artistic experimentation in this medium at the forefront. The leading forums include: " $\mathrm{X}$ 'Teresa Arte Actual Museum, the Arte Alameda laboratory and the Carrillo Gil Museum. The Centro de la Imagen fosters video as an expressive genre in its El D eseo Room. Another space dedicated to the experimentation and dissemination of electronic arts and video is the "Caja Negra project at the University Museum for the Sciences and Arts (MUCA) at Ciudad Universitaria (Zapett, 2003) During that period, an important generation of women emerged in Mexico in the field of audiovisual media and of plastic arts. They decide to use video as a means of sensitive and provocative expression.

Ximena Cuevas (1963) is one of the leading Mexican video filmmakers. Her videos have been shown at international film and video festivals, such as Sundance and the New York Film Festival. She has been invited to speak at many events, such as the one organised by the Pacific Film Archives in San Francisco, the Museum of Contemporary Art in San Diego and the Guggenheim in New York and Bilbao. Her videography boasts works such as Las 3 muetes de Lupe (1983-84), Nohe de Paz (1989), Corazón sangante(1983), Un Dios para Cardlia (1995), Cama (1998), Marca Regjstrada (2001), Tunistas (2001-2002), Plantario (2002) and Tómbda (2003) (Figure 3.1.), which is a documented action on television where she questions the contents of the goggle box. The aesthetics of Carazón sangante are linked to Mexicanidad or the sense of pride of being Mexican, where she follows one of the artistic traditions of Mexican culture and plastic arts. Her contributions to the field of video-installation are also remarkable. In Si la bomba cae(2000), one enters into an "environment" of panels in the Vasarely-style with screens where pirate videos are being shown. In 2009, she produced a video entitled Anatoma demi univeso which was an exercise for the "Anatomy of Video-art" classes, where her closest secrets were shown visually and with sound. She is one of the most acclaimed video filmmakers. In 2001, MO MA in New York purchased nine of her videos for their permanent collection and it was the first time that this institution had acquired the work of a Mexican video filmmaker (Medina \& Debroise, 2006).

Figure 3.1: Ximena Cuevas, tombola, 2003@ artist

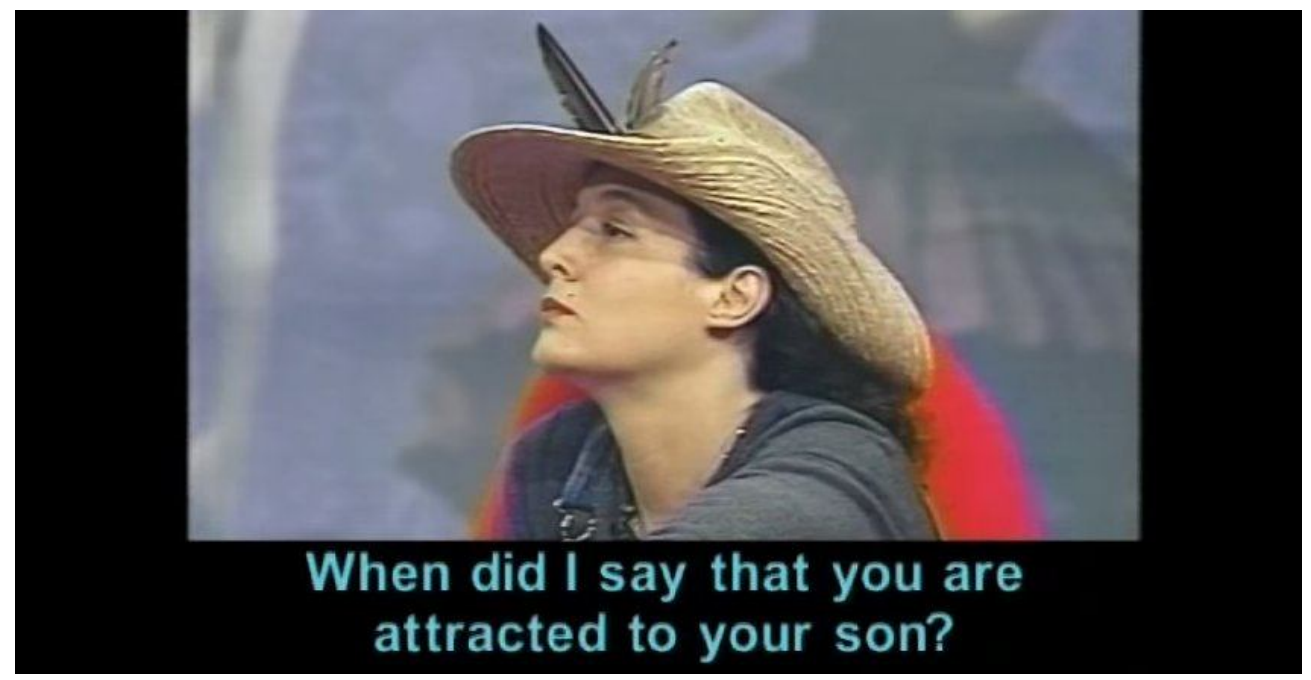

The Mexican tradition survived throughout the 20th century. This tradition provided the setting for the work of Pilar Rodríguez (1962). She investigates the idea of the poetic experience of displacement and the woman-frontier relations. She does not have a very extensive collection which can be referred to as female images. Her most important videos are Laidk quehabitamos (1990) (Figure 3.1.1) and Ella esfrontera (1995). In both works, the Chicanan culture is the key reference, along with the female vision of being Chicanan. 
In La ide quehabitamos she reflects on the situation of the Chicanan women who is always stuck at home. Her poems question the loneliness and identity of a woman who is split in two, as a woman and as Chicanan. This is not a narrative or documentary video, purely a poetic one. Ella esfronterais in the same line, even though loosing one's roots and displacement are seen through a woman split into two.

Figure 3.2 Pilar Rodríguez, La idea que Habitamos, 1990@artista

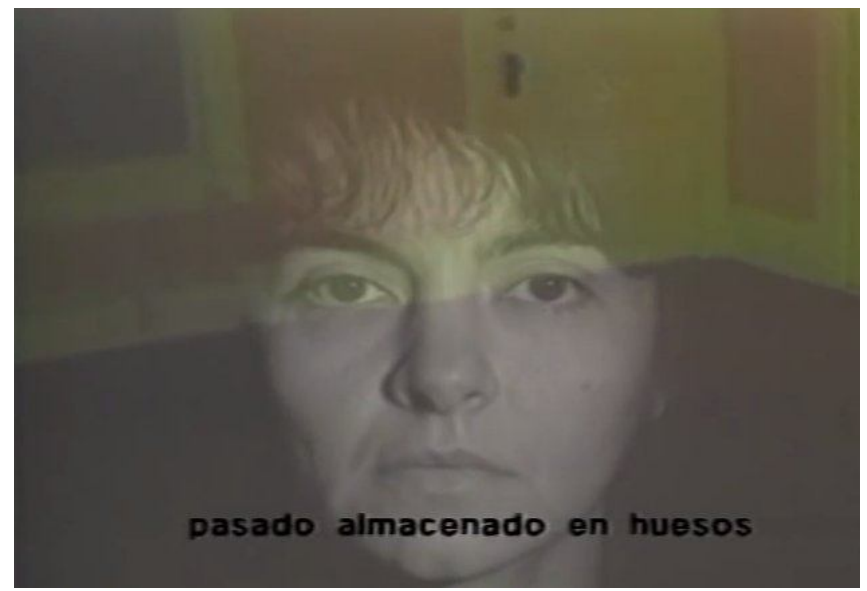

Grace Q uintanilla (1967) belongs to the same generation. She learnt her craft outside Mexico. In 1990, she travelled to Edinburgh, where she studied painting and drawing at the EdinburghCdlegeffArt. She joined the Ednburgh Printmakes Wokshop and the Undewred artists group. She studied traditional film animation at the Edinburgh Film WorkshopTrust. In 1994, she was awarded a British government grant to take a post-graduate course in Electronic Arts and Television at he Schod of Tdeision and Eletronic Imaging Duncan of Jardanstone Cdlege of Art (D undee University, Scotland). In 1996, she returned to Mexico, where she was the runner up at the First National Cultural Television Competition with her Aventurea documentary series. In that same year, her video MamboQueen took first place at the Glasgow Red to Ręl Festival (Scotland). In 1997, she was awarded a FONCA Jóvenes Creadores grant to produce an interactive CD -Rom entitled Vicuesa (Mariategui \& Villacorta, 2005). Viceesa (1998) (Figure 3.1.2) is a multi-media interactive project inspired by the life of two artists on the verge of old age. The main characters are a brother and sister, who grew up in big tops, cabarets, theatres, popular festivals and other events for the masses. They were artists before they could even decide to the contrary, as their parents were already in show business when they were born. They acted, danced and sang from as early as they could remember. In this work, they randomly remember parts of the life of the main characters through their bodies, that is: their stories are reconstructed by "desconstructing" their physical. Chelo and Roberto Cobo (Calambres) worked on this project as co-scriptwriters.

The script is based on their anecdotes and responses to the deconstructed depiction of their bodies. The actor decides when to stop acting to reveal him or herself. In the case of this documentary, they decide to control their image, choosing when to act and when to be themselves. As a director, she just provides images for their memories, to show their lives through their own eyes, thus avoiding the romantic or anthropological depiction of the artist regarding their inspiration object. The body has been their means, companion and a mirror of the memory. Memory is multi-sensory and non-linear. The fact that Viceresa was produced in an interactive format is not just a whim. Due to its fragmentary and non-linear nature, this system is the ideal medium for the conceptual and visual depiction of the story of the characters. Vicuessa plays with the barriers of the documents as a medium, experiments with new narrative opportunities and depicts the memories, anecdotes, fantasies and thoughts of the main characters using animation, video, text and audio. Viceresa shows three main "times" of Chelo and Beto: the past, the present and the profound. The past and present are accessed directly. The past is discovered in the albums that they hold, when they talk about their childhood and their first jobs. The present is seen by clicking on parts of their faces with the mouse. In the present, they talk about their current concerns, old age and their profession. It is necessary to know the present and past to enter into the profound. In the profound stage, Chelo and Beto are nude and talk about their most intimate experiences and their fantasies. 
Figure 3.3 Grace Quintanilla, Viceversa, 1998@artist

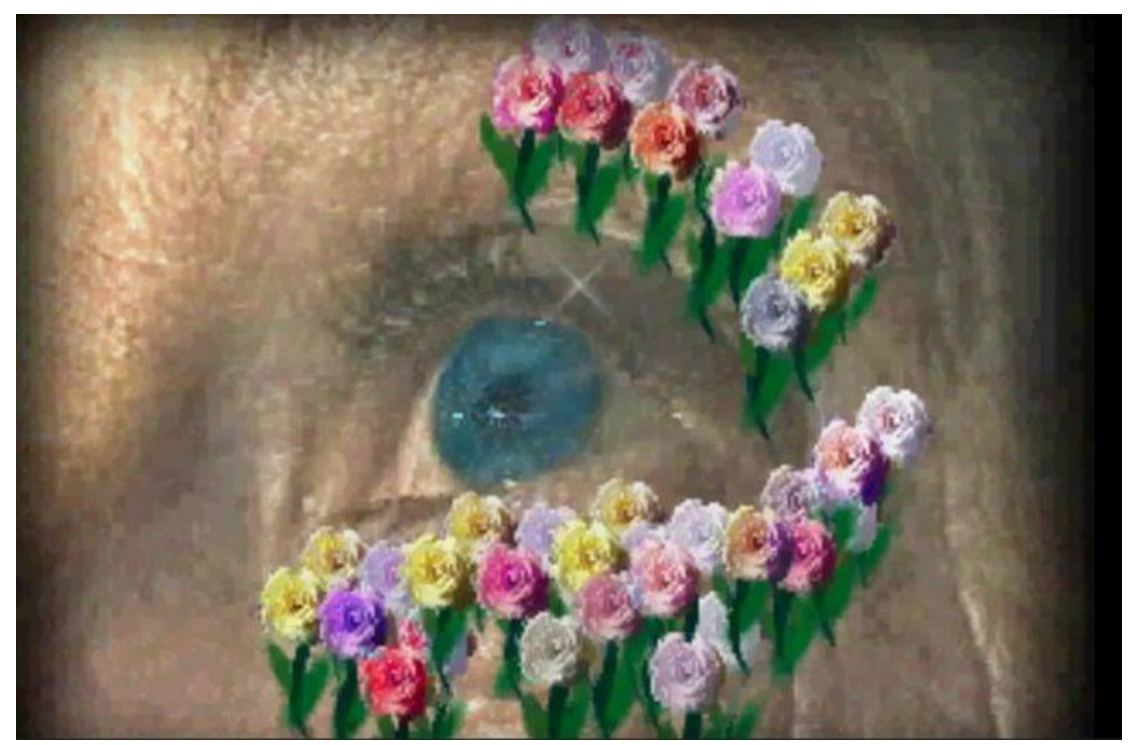

\subsection{Emerging Artists in the 21st Century}

In the $21^{\text {st }}$ century, the digital context has blurred the frontiers through Internet. It has provided very different spaces and discourses used by emerging artists, such as Laura Carmona or Fabiola Torres. The opportunities to exhibit played a key role when video began to be included, as was the case with the Momenta Arte Electrónico (2000) exhibition, held at the Centro Nacional de las Artes and the Inside International Festival of Contemporary Art in San Diego/ Tijuana. Collective offerings have also been developed from artistic practice and organisation, as can be seen from the existence of the "Art in Video Cooperative" at the Tamayo Contemporary Art Museum (2003), which has provided a showcase not only for individual works on the two occasions that it has been held, but also from the collective image of Mexican artists that work in this medium and their external showing in exhibitions such as the one at the Sala Parpalló (Valencia) in April 2008. In 2002, the GUONDERG UOMAN video cycle featured the recent work of acclaimed artists such as Ximena Cuevas, Claudia Fernández, Grace Quintanilla and Cecilia Navarro, together with that of new creative artists, such as Carolina Esparragoza, Paulina del Paso and Amaranta Sáncez. They tackle the daily micro-cosmos of their work without beating around the bush. There are no conspiratorial winks in the middle of the strength and forcefulness of their feelings and reflections. Their offerings are intimate and revealing. The camera nearly always focuses on the producers themselves, stressing the sensation of proximity and fragility of their works. The women reveal themselves, bare themselves, question the imposition of corporal, spiritual and affective parameters. The feminist claims are not necessary and it is the female immediateness and their poetics which becomes a mirror that challenges the viewer to look. They also stir up reflections about the Chicanan culture and position of women in that context (LLanos, 2004).

Carolina Esparragoza (1977) graduated from "La Esmeralda” National School of Painting, Saulpure and Engraving (ENPEG). She has worked with sequential graphics, produced video animation and object art as part of the Malestares project in 2001. She is currently working on La misma historia animation. She has exhibited at La Caja Negra (Mexico), at the MoCA (USA) and in the Buenos Aires Modern Art Museum, to name just a few. Animation has become the focus of her work in this field over recent years. Todas tenemos la misma historia animation short film tackles the gender position established in the new millennium and the existing discriminatory vices. Todas tenemos la misma historia is based on the homonymic play by Darío Fo, the playwright, that consider the problems of the contemporary female universe. Its characters, a child, a rag-doll, a wolf or a wicked witch, seem to have come out of a fairytale. With backing from the Mexican National Fund for Culture and Arts, Esparragoza produced an 8-minute animated story over more than one year. The filmmaker believes that the digital animation genre is one of the strongest experimental areas, as it enables unlikely dreams to be transferred to images. According to Esparragoza, society continues to be related to women with aprons, ovens, washing machines and beauty parlours. Her work process is one of her main contributions together with how she tackles the subject matter and is worthy of a few lines. In order to design the animated figures, Carolina gathers together objects that make up the household universe of women, such as bits of stockings, cosmetics, etc. 
After she has designed each character using those materials, she photographs them, frame by frame, to produce a three-dimensional mould, then she digitalises them and touches them up with the computer. Carolina Esparragoza has produced half a dozen works. However, it is the first time that she includes dialogues. Sharon Toribio (1975) is another of the most versatile video filmmakers in the field of video art and video installation. She studied audiovisual media at the Department of Video and Television at the Universidad de Guadalajara and then at the Audiovisual Art Centre. She was given a "Jóvenes Creadores" grant by the Fondo Estatal de Jalisco and a FO NCA scholarship in 1998 and in 2003. She was a runner up at the vid@ rte Festival with Cita a las Nuae(1997). She has taken part in festivals in Mexico, Argentina, Spain, Chile and San Francisco. Damas dergo (2002), a video inspired by Satilegjos, the poem by Alejandra Pizarnik. She has produced fiction videos, including Juregodeniñas (2006) (Figure 4.1). This was also inspired by the poetic texts of Alejandra Pizarnik about the character of the bloody countess, Elizabeth Báthory, and her torturing of young women in the 16th century. From the same poetic vision, we enter into the dream of seven girls who want to know and play with the Condesa, who wakes up to relive as if in a children's tale her most sordid tortures of her young victims.

\section{Figure 4.1: Sharon Toribio, Juego de niñas, 2006॰artista}

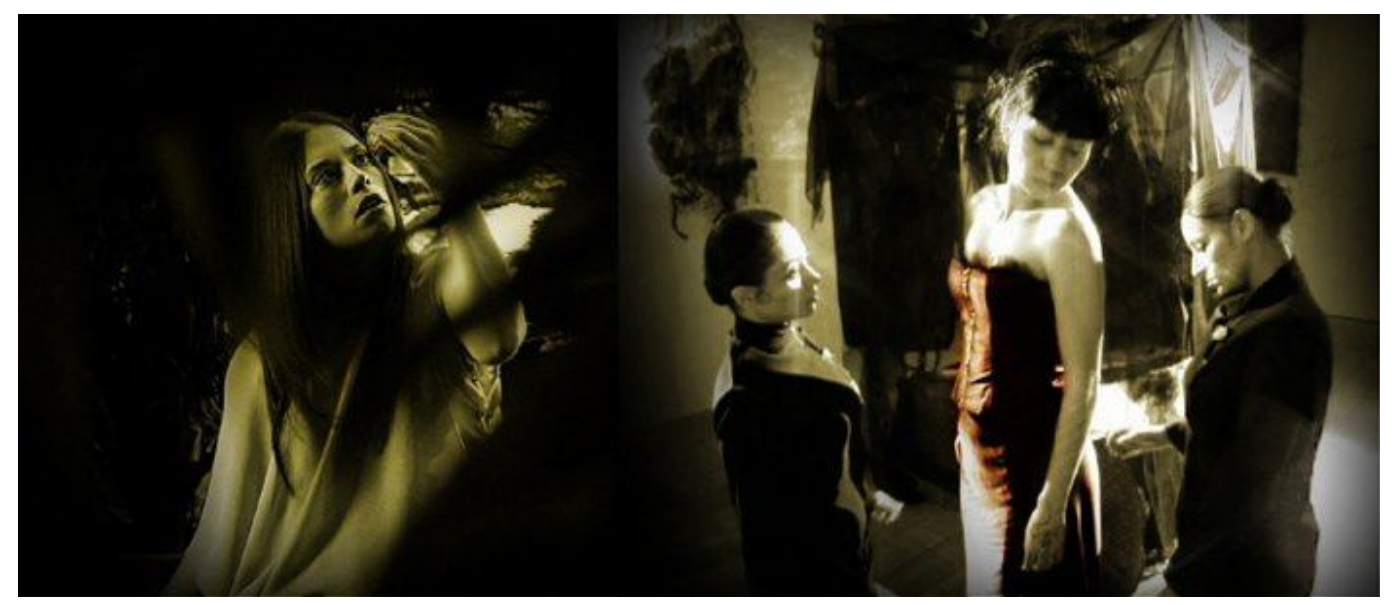

Alejandra Echevarría. She is currently studying for a Degree in Plastic Arts at "La Esmeralda" ENPEG. She was awarded the 1999-2000 FO NCA Jóvenes Creadores scholarship to specialise in Alternative Media (Mexico). Since 1998, her works have been included in over 30 collective exhibitions in international and national forums, such as the Ex Teresa Arte Actual, University Museum for the Sciences and Arts, MUCA Rome VII Bancomer Art Exhibition at the Modern Art Museum, the D olores Olmedo Museum, Enrique Guerrero Gallery and at exhibitions and festivals in France, Japan, Germany, Austria and Hong Kong. In 1999, she was awarded 1st prize for her Yonodeǵ estecueppo yo no soy este auepovideo (1998) in the Experimental Video section at the Electronic Arts and Video Festival in Mexico and the Prize for the Best Video Clip and the Audience Prize for Tienequesalir(1997), at the VIART Video University Festival in Caracas, Venezuela (2000). In 2001, she put on an individual exhibition entitled "Segundas" at the Enrique Guerrero Gallery in Mexico City. Paulina del Paso (1975). Daughter of Fernando del Paso, the author. She trained at the School of Video and Television at the Universidad de Guadalajara and then at the Centro de Capacitación Cinematográfica film school. She was a runner up at the IV Video Biennale in Mexico City. She was awarded a FO NCA scholarship in 1998-1999 and 2001-2002. Her work has been exhibited at the Centro de la Image and the Contemporary University Museum (UNAM). She explores audiovisual languages with the skills of a surgeon and the inspiration of a novelist. Her first video, Mirame y no me toques (1997), revealed her interest in collage and postproduction work. She continued to be interested in these areas and went further into them in her second work, Enun abir y cerar degos (1999), which is notably more complex as it has three different moments of the same story in a single frame, achieved by over-imposing the three shots. The appearance of Fernando del Paso as an actor in this work is particularly noteworthy. Her main concern is not to focus on the technique, but rather on the story that she wants to tell. Her instrument is a compact video camera, which provides her with a great deal of freedom in and simplifies her work. 
With the compact camera, she began to go further into personal subjects, such as being overweight, the theme of a work entitled MagicSulhudte(2001), where she looks at the contemporary obsession with being slim. All of this material has come together in the Automeratos series, noted for its humour and irony, which includes works that consider love, the first kiss - that tasted of meat balls - and the laying down of beauty standards. Las búsqueebs brings together a series of works that are productions using graphic elements that she decided to collect, including photo camera instructions and cleaning rags, together with images taken from television. (Pech, 2009). Her most recent project, for example, is a feature-length documentary about a female boxer from Neza, known as La Guerea (2011) (Figure 4.2), a more traditional work, in which she has already invested three years, which does not mean that she abandoned her other facets.

\section{Figure 4.2 Paulina del Paso, La Guerrera, 2011@artista}

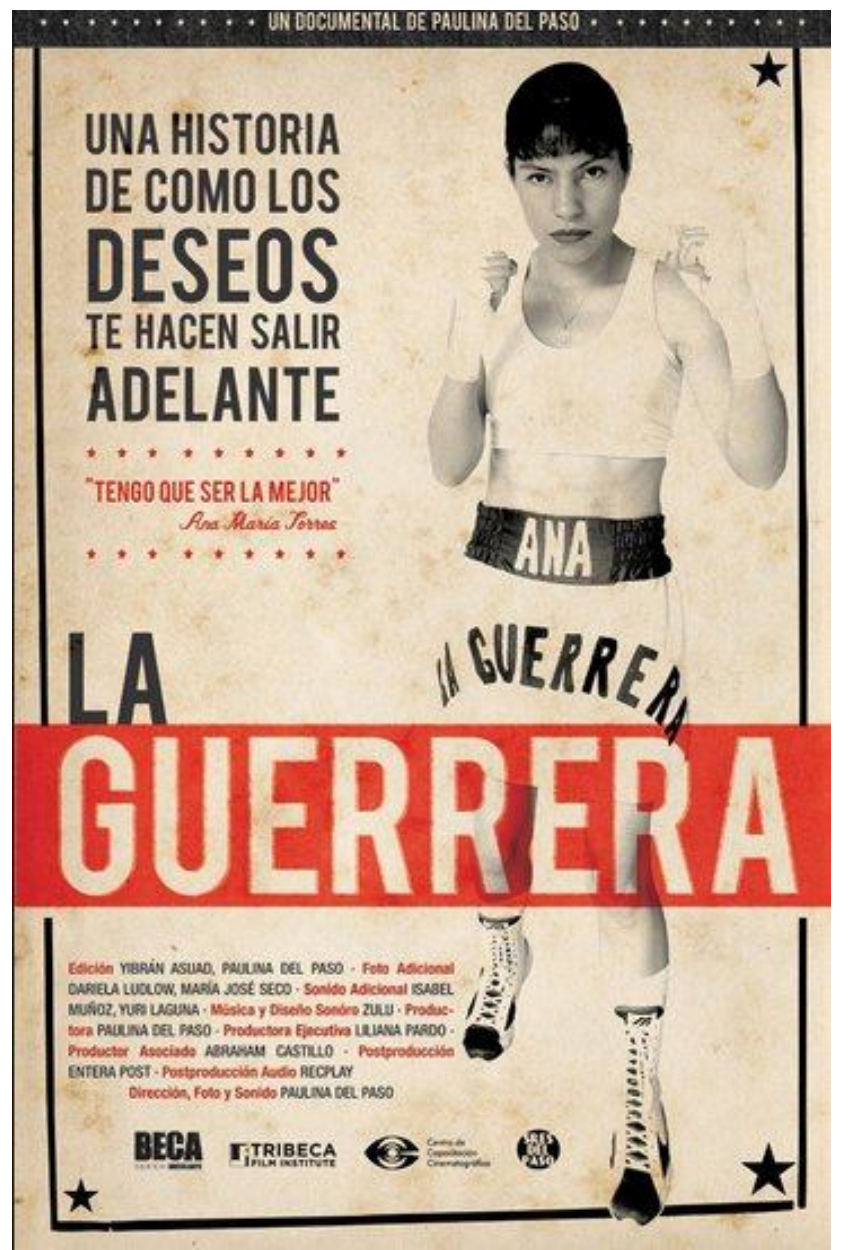

Amaranta Sánchez (1976). She studied art at CEDART D iego Rivera and later enrolled at the "La Esmeralda" National School of Painting, Salptureand Engraving (ENPEG). She specialised in multimedia at the CAN Multimedia Centre. She was awarded a "Jóvenes Creadores" grant (2001-2002) in the area of video/ visual arts. Her professional experience includes designs for CD-ROMs and websites and production design for short films. She has taught elementary sculpture and paint classes. Her works have been exhibited at international and national festivals and museums. Her videos have tackled many different topics, with a special emphasis on gender issues and consumerism. These include Mijer deLujo(1999), Anatomá(2000), Una banda color derosa (2001), Crema denohe(2002), Deshidomanual (2002), Máxima proteción (2002). O ne of her most elaborate videos is 4d4. Cuatrodearatrois the result of one of the first videos of the Monstruo(Monster) series where she uses technology as a means to produce a self-portrait. This video in four movements transforms the monster, a fictitious character from an urban forest, into her reflection. A selfportrait that uses the video as a narrative space to the discursive transformation of the urban landscape. By altering the monster corporeity using the soundtrack, the work that is based on the number four, consists of four pieces, each one of four parts, and each part using four notes. 
A structure constructed by means of original sound resources generated specifically by Jorge Bolado. She produces sounds generated using toy instruments or toys. Each sound is designed in the studio without using any other technology than recording. The editing is crude, without fading in or effects, where she seeks to have a formal parallelism with the thematic and visual offering. A search for candour and innocence within an ominous context without overlooking the small hints of malice. The sound full of irony without moving away from the framework of nature, is a mixture of tenderness and pain, in a threatening and primitive setting that will lead to a discovery (Zúniga, 2009). Nowadays, video art in Mexico is thriving and is increasingly reaching out to the general public. That is the case of the exhibition at the Estación Indianilla Cultural Centre in 2007, which sought to tackle the multi-cultural, the underground, the multi-disciplinary, and which lasted longer than the standard events and provided the time needed for reflections in situ.

\subsection{Concluding Remarks}

Digital medium is becoming more widely used by artists in many different fields. For the last forty years, it has been a highly useful tool to prepare personal speeches, while also being a highly flexible medium for understanding genres and presenting contents. This paper seeks to provide an overview of the situation and the different art offerings on video, produced by women in Mexico during the early 21st century, with a focus on their collective and individual work, and on the different exhibition channels. There are no reference works that compile the history of video-art in Mexico, even though there is a significant group of artists using this medium for their artistic creations. One of the reasons is the difficulties faced by Mexican video producers for many years. The other reason is that film, communication and plastics art communities in Mexico took video-graphic creation on board for different reasons. The 1990s were the turning point where the artists no longer came from other disciplines and started going directly into video.

\section{References}

Baigorri, Laura. (2008). Video en Latinoamérica. Una Historia Crítica. Madrid: Brumaria 10.

Debroise, O., \& Medina, C. (2006). La Era de la discrepancia, Arte y cultura visual en México 1968-1997. México: Museo Universitario de Ciencia y Arte, UNAM.

Elkins, J. (2003). Visual Studies. A Skeptical Introduction. Nueva Y ork: Routlegde.

García, N. M.-e. (2006). Cartografías del feminismo mexicano 1970-2000. México: Universidad Autónoma de México.

González, R., \& Lerner, J. (1998). Cine Mexperimental. 60 años de medios de vanguardia en México. México-EEUU: Fideicomiso para la cultura México-EEUU, Smart Art Press. O btenido de http:/ / www.geocities.com/ mexperimental/

Hernández Miranda, D. (2006). Pola Weiss: pionera del videoarte en México. Veracruz: Ed. Comunidad de Morelos S.A. de C.V. Orizaba.

LLanos, F. (2004). Arte en Vídeo. Antes, ahora y después... aquí. D ossier de Arte, La Revista. El Universal, 39-42.

Malvido Ariaga, A. (1999). Por la vereda digital. Ciudad de México: CO NACULTA / CENART.

Mariategui, J. C., \& Villacorta, J. (Valladolid, Museo Patio Herreriano, Alta Tecnología Andina de 2005). Videografías Invisibles. Una selección de videoarte latinoamericano 2000-2001. Recuperado el 16 de junio de 2013, de http:/ / www.videografiasinvisibles.org/

Medina, C., \& D ebroise, O. (2006). La Era de la discrepancia, Arte y cultura visual en México 1968-1997. México: Museo Universitario de Ciencias y Arte, UNAM.

Millán, M. (1996). Mi Co-Ra-Zon. Pensando el video como tecnología de género. En Coloquio Los Estudios de Género (pág. 15). México: Programa Universitario de Estudios de Género.

Minter, S. (1991-92). Alma Punk. Recuperado el 27 de junio de 2011, de http:/ / sarahminter.blogspot.com/ 2009/ 04/ alma-punk-sarah-minter-fragmento-1991.html

Minter, S. (2006). Hikuri. Recuperado el 4 de mayo de 2012, de http:/ / www.arteven.com/ video/v_sarah_minter_2.htm (Consulta 4-5-2010)

Minter, S. (2006). The first bath. Recuperado el $2 \overline{3}$ de marazo de 2013, de http:/ / www.replica21.com/ archivo/ articulos/ k_l/ 358 llanos_minter.html

Minter, S. (2008). A vuelo de pájaro, el vídeo en México: sus inicios y su contexto. En L. BAIGORRI (Ed.), Vídeo en Latinoamerica: una historia crítica (págs. 159-167). Madrid: Brumaria. 
Minter, S. (2008). Nadie es inocente. Recuperado el 27 de junio de 21011, de http:/ / www.youtube.com/ watch?v=_zl019-59U8

Noriega, C., \& López, A. M. (1996). The Ethnic Eye: Latino Media Arts. Minneapolis: University of Minnesota Press.

Pech, C. (2009). Fantasmas en tránsito. Politicas discursivas de videoartistas mexicanas. México: Universidad Autónoma de México. Fondo Nacional para la Cultura y las Artes.

Pech, C., \& Millán, M. (2006). Género, Representación y Nuevas Tecnologías: Mujeres y Vídeo en México. Revista Mexicana de Ciencias Políticas y Sociales, XLVIII(197), 95-104.

Ranucci, K. (1998). A Guide to Latin American, Caribbean and U.S. Latino Made Film and Video, MD. Lanham: The Scarecrow Press.

Renaud, A. (1990). Comprender la imagen hoy. Nuevas imágenes, nuevo régimen de lo visible, nuevo imaginario. En G. ANCESCHI (Ed.), Videoculturas de fin de siglo (págs. 47-60). Madrid: Cátedra.

Sedeño, A. (2006). Revisión general sobre la vídeocreación en México. Razón y palabra(69), 34.

Zapett, A. (2003). Videoarte en México. Recuperado el 19 de junio de 2012, de http:/ / www.cnca.gob.mx/ disvisu

Zúñiga, A. (2004). Con la luz del milenio, hacia un mestizaje visual. De las extrapolaciones: Pola Weiss. Scáner Cultural, Revsita Virtual, III(62), 10-18. Recuperado el 19 de marzo de 2014, de http:/ / www.escaner.cl/ escaner62mutaciones.html

Zúñiga, A. (2009). El insilio en méxico. Bordo de mi misma. En K. VILLEGAS, Transitio MX03 (págs. 25-33). Ciudad de Mexico: Festival internacional de Artes Electrónicas y Vídeo Transitio_MX03/ Autonomías del desacuerdo. 